\title{
Corporate Ownership Structure and Accuracy and Bias of Mandatory Earnings Forecast: Evidence from Taiwan 公司股權結構和強制性盈餘預測之準確性和偏誤：以台灣上 市櫃公司論析
}

\author{
Chen-Lung Chin \\ Department of Accounting \\ National Chengchi University \\ No. 64, Sec 2, Jhihnan Rd., \\ Taipei City, Taiwan 116 \\ Email: kim@nccu.edu.tw
Gary Kleinman
Department of Accounting and Business Law
Kean University
Union, New Jersey, USA
Email:Gk49593@cs.com \\ Picheng Phil Lee \\ Department of Accounting \\ Lubin School of Business \\ Pace University \\ New York, NY 10038, USA \\ Email : plee@pace.edu \\ Mei-Feng Lin* \\ Department of Accounting \\ National Yunlin University of Science \& Technology \\ 123 University Road, Section 3, \\ Douliou, Yunlin 64002, Taiwan. \\ Tel : +886-5-534-2601-5518 \\ Email: linmf@yuntech.edu.tw
}

This draft: February 2006

*Corresponding Author 


\title{
Corporate Ownership Structure and Accuracy and Bias of Mandatory Earnings Forecast: Evidence from Taiwan
}

\begin{abstract}
The primary objective of this study is to examine the association between the quality of mandatory earnings forecast, measured by forecast accuracy and bias, and the ownership structure of Taiwanese firms, measured by the divergence between the ultimate owner's control and the equity ownership level. The study is based on 528 forecasts issued by Taiwanese listed firms from 1999 to 2001 which were affected by the regulation on disclosure of earnings forecasts issued by the Taiwan Securities and Futures Exchange Commission (TSFEC). First, we find that concentrated ownership and the associated pyramidal and cross-holding structures created agency conflicts between controlling owners and outside investors. Second, we also find that firms tend to issue more inaccurate and optimistically biased forecasts in the presence of the greater divergence between the ultimate owner's control and the equity ownership level. Third, the firms with serious agency problems tended to revise their forecasts more to reduce error or bias or manipulate accruals more (e.g. through discretionary accruals) in order to avoid violating the $20 \%$ forecast error threshold as the end of the period approached. Finally, the resulting post-managed forecast error or bias does not significantly vary with the level of ownership concentration
\end{abstract}

Key words: ownership structure, mandatory earnings forecasts, earnings management, financial disclosure, information environments 


\section{Corporate Ownership Structure and Accuracy and Bias of Mandatory Earnings Forecast: Evidence from Taiwan}

\section{Introduction}

The low level of information transparency and disclosure quality that is typical of public corporations in the East Asian region, including Taiwan, leads to high financing costs in this region. High information asymmetry and low accounting quality, and the associated high cost of capital, pose a potential threat to the competitiveness of East Asian firms. Despite efforts by area regulatory agencies to impose stricter accounting reporting rules, corporate transparency is still declining. While the new accounting rules have been issued and may have increased the quantity of accounting information, investors still do not trust the quality of the reported numbers (Fan and Wong, 2002). It is important, therefore, for regulators and researchers to understand why reported financial information in the region has low credibility.

This study examines the relationship, in Taiwan, between corporate ownership structure and mandatory earnings forecast quality, as measured by the latter's accuracy and bias. While prior literature on corporate governance acknowledges the importance of accounting information, it typically treats the quality of this information as exogenous and does not distinguish between stated accounting and firm's actual reporting practices (e.g., La Porta et al., 1998). Using Taiwanese listed firms, this paper focuses on corporate governance as a significant determinant of the quality of mandatory earnings forecasts in the context of so-called insider economies (Leuz et al., 2003). The latter are characterized by smaller stock markets, higher ownership concentrations, weaker investor protections, and required lower disclosure levels.

In response to the growing concern about the dearth of information about firms issuing equity or debt, the Taiwan Securities and Futures Exchange Commission (TSFEC) 
issued "Guidelines for Disclosure of Financial Forecasts by Public Companies” in 1991. These guidelines required Taiwanese firms to include earnings forecasts in their prospectuses for years in which they raise additional capital. ${ }^{1}$ The firms are also required to disclose the earnings forecast for two years after the debt or equity issuance. The main motivation for this was to reduce the information asymmetry between investors and firms. ${ }^{2}$ The regulation's advocates expected that broader information dissemination would mitigate selective disclosure by firms, thereby promoting information provision. Mandatory forecast requirements exist in Singapore, Malaysia, and Taiwan. They are believed to signal the firm's future prospects and thus be useful in assessing the firm's fundamental value. The existence of mandatory forecast requirements presumably eliminates problems of voluntary forecasts (in the US) reported in Karamanou and Vafeas (2005).

Prior studies have documented that corporate ownership structure is related to accounting earnings credibility in East Asia (Fan and Wong, 2002; Haw et al., 2004). The concentrated corporate ownership structures in East Asia create agency problems between the minority owners and the controlling owners. ${ }^{3}$ The latter generally possess control (voting) rights in excess of cash flow rights via stock pyramids and crossownership structures. The greater voting rights give the controlling owners greater power and incentive to influence the decisions that the firm makes and to expropriate firm

\footnotetext{
${ }^{1}$ The preparation of financial forecasts shall be subject to the Statements of Financial Accounting Standards No. 16 "Preparation of Financial Forecasts" published by Taiwan's Accounting Research and Development Foundation.

2 The TSFEC's administrative rule (No. 82-Taiwan-Finance-Securities-(VI)-02581 issued on October 30, 1993) mentions that disclosure of forward looking information will reduce information gap between informed and uninformed traders, and this will finally prevent the use of inside information for making arbitrary profits.

${ }^{3}$ The term minority investors is used by Haw et al. (2004) and Fan and Wong (2002) to refer to investors who are not part of the controlling group or family. We use the term here to be consistent with this prior literature.
} 
assets $^{4}$. The controlling owner's smaller cash flow rights mean that he/she has the right to receive a smaller share of the cash distributable or distributed by the corporation. Therefore, the owners' share of losses from wealth extraction is diminished. ${ }^{5}$ In sum, as control divergence increases, the controlling owner's ability and incentive to expropriate minority investors increases also. ${ }^{6}$

Asset expropriation is most feasible when the controlling owners and managers can conceal their activities from the so-called minority owners. Concealment may be accomplished via the controlling owner's control over financial reporting. Such control reduces external parties' ability to discover any expropriation, and therefore trigger disciplinary action against the controlling owner group (e.g., Shleifer and Vishny, 1997). According to Haw et al. (2004), earnings management rises concomitantly with control divergence. In addition, Fan and Wong (2002) reported that the control divergence of interest here negatively impacted the informativeness of earnings reports to investors.

In this paper, we expect that the quality of mandatory earnings forecasts will be affected by increasing levels of control divergence. Relative to other countries in East Asia, another key factor that exacerbates the agency conflicts arising from the control divergence is that there is no check on the controlling owners' self-serving behaviors by boards of directors, external institutional investors, or takeover markets (Yeh, Lee, and

\footnotetext{
${ }^{4}$ Example of such private control benefits range from excess perquisite consumption to the transfer of firm assets to other firms owned by the controlling owners or their families.

${ }^{5}$ Such phenomena as tight control by some publicly owned corporations is sometimes seen in the United States as well. For example, see Lavelle (8/25/2004), Morgenson (2004), and Frank and Cherney (2004) with regard to Google's IPO and provisions that entrenched the ruling triumvirate at Google, Fidelity Investments alleged conflict of interest between advisory fees that it earned from Intel and Fidelity's investments in Intel, and the Lord Black/Hollinger affair, respectively.

${ }^{6}$ Claessens et al. (2000, p. 84) cites La Porta et al.'s (1999) statement that in East Asia, corporate control can be achieved while holding much less than an absolute majority of the stock. In that area, the probability that a single controlling owner holds less than $20 \%$ of the stock is very high. This held true in 80\% of the cases, across the four East Asian countries. Claessens et al. (2000) reported that the average voting rights held by controlling shareholders in Taiwan was about $18.96 \%$, while the average cash flow rights held by controlling shareholders in Taiwan was about $15.98 \%$.
} 
Ko, 2002). In addition, the latter two are unlikely to have access to relevant information on the firm's true condition or prospects. We argue therefore that, pursuant to the TSFEC's disclosure requirement, controlling owners have incentives to release inaccurate earnings forecasts in order to mask true firm performance (Haw et al.'s (2004) term) and thereby to avoid having new share issuance proceeds negatively affected by the controlling owner's opportunistic behavior. We expect that greater control divergence will be related to a greater likelihood of issuance of less accurate forecasts.

We expect, however, that the effect of control divergence on earnings forecasts will be asymmetric. Issuing more optimistic earnings forecasts gives the controlling owner greater opportunities to extract additional wealth from the firm. The result of this opportunistic behavior is that the firm will issue stock or bond (raise capital) at a higher price than the shares or bond would otherwise command. This would result in (a) an increase in the market value of the controlling owner's shareholdings; (b) an increase in a firm's raised proceeds; and (c) an increase in ability and incentive of controlling owner's to private control benefits extraction. Haw et al. (2004, p. 428) described these as "perquisite consumption, excessive managerial pay, appropriation of the firm's opportunities and assets, and outright theft.” Appropriation of the firm's assets may specifically include the transfer of firm assets to other firms owned by the controlling owners or their families (Yeh, Lee, and Ko, 2002). Prior research (Chin et al., 2002; Jaggi et al, 2006) has documented that, on average, Taiwan-listed firms are more likely to issue optimistic, rather than conservative, forecasts. We argue here that firms with greater control divergence are more likely to release inaccurate and optimistically biased forecasts than are firms with less control divergence. 
To help assure earnings forecast accuracy, the TSFEC regulation stipulates that firms that exceed the forecast error threshold ${ }^{7}$ must receive special permission before raising additional capital. ${ }^{8}$ We examine whether forecast errors and biases are reduced as the year end approaches, whether through adjusting actual earnings or by revising earnings forecasts themselves. We believe that firms with more serious agency problems are more likely to do this.

The remainder of this study is organized as follows. Section 2 briefly reviews the governance environment and TSFEC disclosure regulations relevant to the current study. Section 3 develops the hypotheses. Section 4 provides the model specifications, variable definitions, and sample selection procedures. Section 5 reports descriptive statistics and the results of the empirical tests. Section 6 presents our discussion.

\section{Corporate Ownership Structure and Disclosure Regulatory Environment in} Taiwan

\subsection{Corporate Ownership Structure in Taiwan}

The corporate governance system in East Asia is typified by a high concentration of ownership, family-controlled business groups, and a relative lack of major institutional investors (Claessens et al., 2000). Family ownership or control is a common characteristic of Taiwanese corporations (see Ko, Ding, Liu and Yeh, 1999). In Taiwan, the ultimate owners leverage their resources through the use of pyramiding and management appointments, as well as through cross-ownership arrangements and use of share classes that have more votes than others. According to Ko et al. (1999), major

\footnotetext{
${ }^{7}$ The threshold was initially set at $10 \%$ level in June 1991 . The $10 \%$ threshold was, however, considered to be quite stringent for IPO firms in a volatile economic environment, therefore it was revised to $20 \%$ in January 1994.

${ }^{8}$ The TSFEC regulation has placed no limit on the number of revisions so long as the revisions are issued before the actual earnings are reported.
} 
institutional investors seem to lack interest in corporate governance in Taiwan. Thus these investors cannot play an effective role in corporate governance. Such disciplinary tools as takeovers and hostile bids are not effective mechanisms for corporate control primarily because of the predominance of concentrated family ownership.

\subsection{Disclosure regulation}

The Taiwanese financial information environment lags behind that in the West. Lagging environmental features include relatively limited analyst following and poorer firm-related general news coverage than is available in the West. ${ }^{9}$ Compared to the US, securities-related class action lawsuits are rare in Taiwan. As a consequence, Taiwanese firms find it safer to choose less rigorous financial reporting methods. ${ }^{10}$ The result is increased information asymmetry.

The TSFEC's “Guidelines" were an attempt to simultaneously strengthen the operating efficiency of the Taiwanese equity market, reduce information asymmetry, and remedy the market's failure to produce quality financial forecasts. ${ }^{11}$ In order to assure board accountability, the regulations require that management earnings forecasts must (a) be approved by both the board of directors and supervisors, and (b) not deviate from reported earnings by more than $20 \%$. If management forecast errors exceeded the $20 \%$ threshold, firms had little chance of success in subsequent debt and equity offerings. Thus

\footnotetext{
${ }^{9}$ Both academic research (e.g. Yeh, Shu, and Huang, 2001) and some insightful business news comments (See Taipei Times, 18 July 2002 and Zun, 2002) provided anecdotal evidence to criticize analyst bias, earnings management, and a lack of transparency in the financial statements. Similar issues seem to exist in the US, giving impetus to Title V, Section 501(a) of the Sarbanes Oxley Act of 2002.

${ }_{10}$ The recent (September 20, 2004) Wall Street Journal report on alleged earnings manipulation at Fannie Mae, however, shows that these behaviors are still alive and well in the United States. (McKinnon and Hagerty, 2004)

${ }^{11}$ The preparation of the financial forecasts is subject to the requirements of the Statements of Financial Accounting Standards No. 16 "Preparation of Financial Forecasts". SFAS 16 is published by the Accounting Research and Development Foundation of Republic of China (Taiwan).
} 
the firms’ capability for future financing would be greatly impaired since such financing would require the TSFEC's approval. ${ }^{12}$

Information asymmetry enables the controlling owners to simultaneously conceal their private perquisite consumption and, prospectively, boost the image of the company with the result that future share issuance may bring higher prices for both the firm and the owners (e.g. Teoh, et al., 1998; Clarkson, et al., 1992). The relative importance of concealing private perquisite consumption and profits gleaned from over-priced shares cannot be known.

In the context of mandatory earnings forecast requirements, the controlling owners may benefit because required forecast production may lend these forecasts greater credibility than they otherwise might have. Accordingly, the wealth of the controlling owner group may be enhanced (for relevant indirect evidence, please see Wang, Chin, Lee and Kleinman, 2005). Taiwan's regulations require issuing firms to revise their forecasts as new information becomes available. Thus, the issuing firm always has the option of issuing inaccurate or biased forecasts in order to promote higher stock market prices, and revising those numbers as the actual earnings report release date nears. They thereby avoid penalties for providing erroneous forecasts. Reputational effects of making chronically incorrect forecasts aside, the controlling group enjoys the best of both worlds. First, they can issue optimistically biased forecasts to achieve their ends (see Williams, 1996: cited in and from Karamanou and Vafeas, 2005). Second, they can revise their forecasts or use earnings management techniques to avoid violating the $10 \%$ threshold set forth in the regulations.

\footnotetext{
${ }^{12}$ Please note that in 2002, the Taiwan adopted new regulations regarding the financial reporting practices of new IPO firms. These rules were applicable to firms that listed after February, 2002. This adoption does not affect our results since it occurred after the time period covered by our data.
} 


\section{Hypotheses}

Share ownership structure both delineates a firm's agency problems and also affects firm financial reporting. Previous research has almost exclusively focused on U.S. corporations where shares are typically widely owned. ${ }^{13}$ Given that an owner may effectively control a firm, he or she also controls the firm's production of accounting information and the choice of its reporting policies (Fan and Wong, 2002). The accounting literature contains extensive research and theorizing on how the agency problem between owners and managers affects the role of accounting in management compensation contracts and on how the reporting incentives of managers affect a firm's accounting information quality (e.g., Jensen and Meckling, 1976; Rajgopal et al., 2002). These studies document that, in a diffuse ownership context, more managerial ownership is associated with greater earnings informativeness. Based on the work of Jensen and Meckling (1976) and others, it has been argued that increasing managerial ownership acts to align the interests of managers and shareholders, thereby reducing the conflict of interest between them.

In contrast, the relationship between ownership structure and financial reporting has not been studied in a concentrated ownership context like that in Taiwan, the dominant context outside the US. In East Asian corporations, the high concentration of ownership nullifies the principal-agent problem between owners and managers as well as the related role of accounting-based managerial contracts. Instead, the real conflict is between minority owners (a term used by Haw et al., 2004) and the controlling owners. The latter enjoy almost total control over both managerial personnel (Shleifer and Vishny,

\footnotetext{
${ }^{13}$ For example, Dechow et al. (1996) examine effect of corporate governance on SEC enforcements actions. Klein (2002) and Rajgopal et al. (2002) examine the effect of corporate governance on earnings management. Karamanou and Vafeas (2005) and Ajinkya et al. (2005) examine the effect of corporate governance on management earnings forecasts.
} 
1997) and financial disclosure decisions. The desire to maintain their private control benefits implies that the controlling owners need to avoid external monitoring. This can be done by managing reported accounting earnings (e.g., Haw et al., 2004). A key consequence is reduced earnings informativeness (Fan and Wong, 2002). Obviously this may also lead to reduced earnings forecast informativeness.

Our interest is in determining whether the controlling owners seek to reduce monitoring from outside investors by issuing less accurate mandatory earnings forecasts when they raised capital, thereby avoiding potential consequences of self-serving wealth extraction. When inaccuracy results in a more positive picture of the company's prospects than is appropriate, the inaccurate forecast may promote higher future prices on stock issuance or resale. In years of good earnings, firms can also underestimate forecasted earnings to create reserves for future periods.

Taken together, controlling owners mask their private control benefits by releasing less accurate earnings forecasts, reducing the likelihood of outside intervention by masking the firm's performance. These insights suggest the testable hypothesis, stated in alternative form:

\section{H1: Ceteris paribus, the greater the control divergence, the less accurate will be the firm's initial forecast of earnings.}

It is well-documented that earnings forecasts provide an additional mechanism to communicate information about the firms' future prospects (e.g., Patell, 1976; Ajinkyua and Gift, 1984; Waymire, 1984). Frankel, NcNichols, and Wilson (1995) provide

evidence that is consistent with the notion that management earnings forecasts aid the firm in raising capital. Taiwanese-listed firms are required to issue mandatory earnings 
forecasts when they want to raise capital through the securities markets. Prior studies reported that the mandatory requirement encourages managers to issue more optimistic forecasts in order to obtain higher issuance proceeds (also see Jaggi et al., 2006).

In Taiwan, the ultimate (controlling) owners use their control over firms to benefit themselves at the expense of smaller shareholders. The likelihood and level of wealth expropriation are likely to increase concomitantly with the degree of the agency problem. For example, Yeh et al (2002) document that the adverse affect of related party transactions on firms is positively associated with the degree of control divergence. Hence, we argue that ultimate owners employ their power over financial reporting to overstate current and future earnings, thereby promoting the market value of their holdings (Jaggi et al. 2006) and concomitantly conceal past and current wealth exploitation, and promote future wealth exploitation. Accordingly, the ultimate owners have incentives to release optimistic forecasts to protect and improve their own economic position.

This suggests that the probability of an optimistic forecast bias increases as control divergence increases. This reasoning leads to the following hypothesis, stated in alternative form:

\section{H2: Ceteris paribus, the greater the control divergence, the more optimistic will be the forecasts of the firm's future earnings.}

In order to reduce information asymmetry for firms with access to the capital market, the TSFEC issued a regulation that required that Taiwanese firms include earnings forecasts in their prospectuses, setting penalties for firms that exceeded the threshold of forecast error set by the standard. As Jaggi et al. (2006) noted, the final 
forecast before the release of actual earnings was required to be within $20 \%$ of actual earnings. Since firms were and are permitted to issue as many preliminary forecasts as the situation and receipt of new information seemed to warrant, managers had (and have) the ability to make sure that the threshold is not violated.

Firms have two basic options in achieving earnings forecast accuracy, however. On the one hand, the firms can increase forecast accuracy by altering the forecast itself. On the other hand, they can reduce forecast error by revising and/or manipulating discretionary accruals (Jaggi et al, 2006; Kasznik, 1999).

Therefore, we expect that firms with greater control divergence will tend to revise their initially inaccurate (or biased forecasts) more, and/or manipulate discretionary accruals more in order to meet the forecast ceiling requirement. Either approach can reduce forecast errors, thereby increasing forecast accuracy and decreasing forecast bias. Firms with greater control divergence are initially more likely to issue inaccurate and biased forecasts, which require much greater adjustment. This implies that these firms will then have to make greater revisions to either earnings forecasts and/or manipulate discretionary accruals more in order to have acceptably accurate final earnings forecasts. The reasoning suggests another two hypotheses, stated in alternative form:

H3: Ceteris paribus, forecast accuracy is increased more for firms with a greater degree of control divergence as the end of the fiscal year approaches.

H4: Ceteris paribus, forecast bias is decreased more for firms with a greater degree of control divergence as the end of the fiscal year approaches.

\section{Sampling and data sources}

\subsection{Data source and Basic Statistics}


Our sample includes Taiwanese publicly-listed non-financial companies. Sample data covered the years from 1999-2001. The corporate ownership structure data, including control rights, cash rights, and stock pyramids, cross-shareholdings, etc., were collected from the Taiwan Economics Journal (TEJ) database, company prospectuses and "Business Groups in Taiwan”. The latter is a book published annually by the China Credit Information Services LTD. The mandatory forecast and financial information were retrieved from the TEJ database. Our sample firm-years meet the following requirements: That the TEJ database contained the required financial data for all necessary variables and mandatory forecast data. Further, corporate ownership structure data, including control rights, cash rights, and stock pyramids, cross-shareholdings etc., had to be available from the Taiwan Economics Journal (TEJ) database, company prospectuses and the book "Business Groups in Taiwan”. Additionally, firms in regulated industries, finance, banking, and utilities are excluded from the sample since their incentives may differ from those in non-regulated industries (e.g. Jaggi et al., 2006). The above requirements resulted in a sample of 528 firm-years.

There were 1125 prospectuses available for the sample period. Thirty-six firms in regulated industries were deleted. Another 444 prospectuses lacked forecasts, and were deleted. Finally, 117 firms were deleted due to other missing data. The final sample totaled 528. Table 1 presents a distribution of the sample by firm years and industry. Electronics industry firms comprised $53.22 \%$ of the sample. No other industry exceeded $6 \%$ of the sample.

[Insert Table 1 here]

\subsection{Forecast Errors and discretionary Accruals}


Below, we describe the creation of the variables. Table 2 presents capsule variable descriptions.

\author{
[Insert Table 2 here]
}

\title{
Calculation of Forecast Errors
}

Forecast errors (FE) are calculated as the difference between predicted earnings (PE) and actual earnings (AE) deflated by total assets at the beginning of year. If $\mathrm{FE}$ is greater than zero, predicted earnings are higher than actual earnings. These are referred to as optimistic forecasts. Calculations of forecast errors can be based on initial predictions $\left(\mathrm{PE}_{\mathrm{IN}}\right)$, first revision of predictions $\left(\mathrm{PE}_{\mathrm{FR}}\right)$, or last revision of prediction $\left(\mathrm{PE}_{\mathrm{LR}}\right)$. Most forecasts were revised only once, however. Similarly, reported actual earnings (RE) and pre-managed actual earnings (PME) can be used to calculate forecast errors. The PME is obtained by deducting total discretionary accruals (TDA) from the reported earnings (RE):

$$
\mathrm{PME}=(\mathrm{RE}-\mathrm{TDA})
$$

We calculate two forecast errors to evaluate the magnitude of forecast errors at different stages of the forecast error reducing process. First, we calculate forecast errors based on deviations between initial predicted earnings $\left(\mathrm{PE}_{\mathrm{IN}}\right)$ (without any revisions) and pre-managed actual earnings (PME), and term it FE1. It signifies the relative magnitude of differences between initial forecasts and pre-managed earnings, and shows the amount of forecast error reduction needed to meet the forecast error threshold.

$$
\mathrm{FE} 1=\left(\mathrm{PE}_{\mathrm{IN}}-\mathrm{PME}\right) / \text { Total Asset }
$$

Second, we calculate forecast error based on the last revision of forecasts and reported earnings, and denote this FE2. It signifies the magnitude of forecast errors after 
forecasts are revised and earnings have been adjusted by using discretionary accruals. It also indicates whether reported earnings are within the $20 \%$ forecast error threshold.

$$
\mathrm{FE} 2=\left(\mathrm{PE}_{\mathrm{LR}}-\mathrm{RE}\right) / \text { Total Asset }
$$

\section{Calculation of Discretionary Accruals}

Most earlier studies have used total discretionary accruals (TDA) to evaluate earnings management. Here, we use the performance-adjusted model suggested by Klein (2002) and Kothari et al. (2005) to calculate TDA. Total discretionary accruals (TDA) are estimated from the following cross-sectional model:

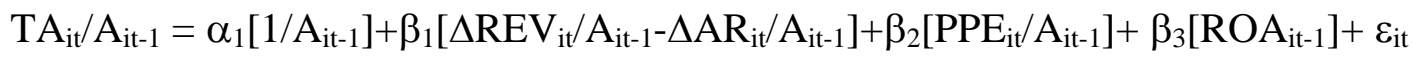

Where, TA, A, REV, AR, PPE, and ROA present total accrual (i.e. the difference between net income before extraordinary items and operating cash flows), total assets, revenues, gross property plant and equipment, and operating income by total assets, $\mathrm{i}$ and $\mathrm{t}$ are subscripts for firm and year, respectively, and $\varepsilon_{\mathrm{it}}$, the residual, is our measure of total discretionary accruals (TDA) for i firm in year t.

\subsection{Measuring the ultimate owners' control and ownership levels}

The definition of ownership structure used takes into account not only so-called immediate ownership (X buys a share of stock in firm $\mathrm{Y}$ and therefore is the immediate owner of that share), but also more complicated forms of ownership (e.g., indirect ownership through nominee stockholders, etc.). This focus on ultimate ownership is consistent with Claessens, Djankov, and Lang (2000), as is our methodology (see also La Porta et al., 1999). For each firm, we identified the ultimate owners via a determination of each share of voting and cash flow rights. As Claessens et al. (2000) argue, control is a 
function of voting rights while rights to proceeds of the corporation are a function of cash flow rights.

We also identified family groupings that controlled firms in our sample. Our procedures in ferreting out chains of ownership closely followed Claessens et al. (2000) and La Porta et al. (1999). This enabled us to delineate the possessors of cash flow versus voting rights. We further followed Claessens et al.'s (2000) methodology in measuring indirect voting right strength. ${ }^{14}$ In our sample, as in Claessens et al. (2000) and Fan and Wong (2002), Taiwanese corporations exhibited high levels of concentration of control. The mean (median) holding of voting rights by the ultimate owners in this sample is $22.79 \%$ (19.66\%) exceeds the mean (median) of cash flow rights, $17.5 \%$ (14.13\%), consistent with prior literature (e.g., Fan and Wong, 2002; Claessens et al., 2000; 2002). The mean proportion of cash flow rights to voting rights $(\mathrm{CV})$ in our sample was 0.79 , clearly indicating a significant divergence between voting and cash flow rights, and that the sample Taiwanese firms are characterized by a separation of ownership and control. ${ }^{15}$ Claessens et al. (2000) and La Porta et al. (1999) posit that the control of East Asian corporations can be achieved with significantly less than an absolute majority share of the stock, as the probability of being a single controlling owner through holding only $20 \%$ of the stock is very high (above $80 \%$ across the four East Asian countries).

\footnotetext{
${ }^{14}$ We follow Claessens et al.'s (2000) methodology in calculating, and distinguishing between, voting rights and cash flow rights. We offer a simple pyramidal structure to illustrate this point. If firm A held $20 \%$ of the shares of firm B, and firm B owned $10 \%$ of the shares of firm C, we would attribute to A control over $10 \%$ of the shares of firm C. With respect to cash flow rights, we again followed the Claessens et al. example. These authors assumed that if firm X owned $20 \%$ of firm Y, and firm Y owned $10 \%$ of firm $\mathrm{Z}$, then firm $\mathrm{X}$ had the right to $2 \%$ of the cash flow of firm $\mathrm{Z}$.

${ }^{15}$ Claessens et al. $(2000,2002)$ reported that the average cash flows rights and average voting rights and held by the controlling shareholders in Taiwanese listed companies were about $16 \%$ and $19 \%$, respectively, and the average cash flow rights over voting rights at 0.83 , which are very close to those in our paper.
} 


\section{Empirical Models}

\section{Accuracy, Bias, and Corporate Ownership Structure}

To verify the validity of hypotheses 1 and 2 , and to understand the association of various variables with financial forecasting, ownership structure, and corporate governance, we chose all of the companies with mandatory forecasts listed on the Taiwan Stock Market to begin our modeling analysis:

$$
\begin{aligned}
\operatorname{ABS}\left(F E 1_{\mathrm{it}}\right)= & \beta_{0}+\beta_{1} \mathrm{CV}_{\mathrm{it}}+\beta_{2} \mathrm{CROSS}_{\mathrm{it}}+\beta_{3} \mathrm{LSHAR}_{\mathrm{it}}+\beta_{4} \mathrm{SIZE}_{\mathrm{it}}+\beta_{5} \text { HORIZON }_{\mathrm{it}}+ \\
& \beta_{6} \mathrm{LOSS}_{\mathrm{it}}+\beta_{7} \mathrm{MB}_{\mathrm{it}}+\beta_{8} \mathrm{ELEC}_{\mathrm{it}}+\varepsilon_{\mathrm{it}} \\
\mathrm{FE}_{\mathrm{it}}= & \beta_{0}+\beta_{1} \mathrm{CV}_{\mathrm{it}}+\beta_{2} \mathrm{CROSS}_{\mathrm{it}}+\beta_{3} \mathrm{LSHAR}_{\mathrm{it}}+\beta_{4} \mathrm{SIZE}_{\mathrm{it}}+\beta_{5} \text { HORIZON }_{\mathrm{it}}+ \\
& \beta_{6} \mathrm{LOSS}_{\mathrm{it}}+\beta_{7} \mathrm{MB}_{\mathrm{it}}+\beta_{8} \mathrm{ELEC}_{\mathrm{it}}+\varepsilon_{\mathrm{it}}
\end{aligned}
$$

In equation (5), $\mathrm{ABS}\left(\mathrm{FE} 1_{\mathrm{it}}\right)$ is used to measure forecast accuracy, and in equation (6), $\mathrm{FE} 1_{\mathrm{it}}$ is a proxy of the extent of forecast error. The more significant $\mathrm{ABS}\left(\mathrm{FE} 1_{\mathrm{it}}\right)$ is, the less accurate earnings forecasts are. We use one proxy variable for corporate governance: The ratio of cash flow rights to voting rights of the largest ultimate owner, $\mathrm{CV}_{\mathrm{it}}{ }^{16}$ to proxy for the positive incentive effect. To be consistent with $\mathrm{H} 1$ and H2, we expect that the coefficient of $\mathrm{CV}_{\text {it }}$ will be negative. The $\mathrm{CV}_{\mathrm{it}}$ variable has been used in various studies (e.g., Fan and Wong, 2002, 2005; Claessens et al., 2000; Claessens et al., 1999; La Porta et al., 2002).

The ultimate owner's control is typically achieved through complicated stock cross shareholdings (e.g., La Porta, R., F. Lopez-de-Silanes, and A. Shleifer, 1999.). We construct an indicator, $\mathrm{CROSS}_{\mathrm{it}}$, which is set equal to one if either (a) the firm has both a

\footnotetext{
${ }^{16}$ In additional analyses, we used three other variables to proxy for the degree of incentive alignment effects. They are: 1$) \mathrm{CFR} 1_{\mathrm{it}}$, which is defined as the ratio of cash flow rights to the industry median for that year, 2) CFR2 $2_{i t}$, which is defined as the ratio of cash rights minus the industry median for that year of the largest ultimate owner, and 3) $\mathrm{DIFF}_{\mathrm{it}}$, the difference between voting rights and cash flow rights of the largest ultimate owner. These three variables and CV are very highly correlated. Use of these variables in secondary analyses did not change the conclusions of the research.
} 
controlling shareholder and owns shares in that controlling shareholder, or (b) owns shares in a firm that belongs to its chain of control (Claessens et al., 2000). CROSS $_{\text {it }}$ equals zero otherwise. ${ }^{17}$ Taiwan's Corporate Law 214 stipulates that shareholders who have continuously held $3 \%$ or more of the firm's outstanding shares for more than one year may initiate, on the company's behalf, an action against a director of the company. Such stockholders in effect serve a monitoring role, helping to mitigate agency conflicts. To examine the effect of this, we construct an indicator variable that equals one if a socalled "Large" shareholder of the firm exists, and equals zero otherwise. The use of a dummy variable to measure LSHAR is consistent with other literature (e.g., La Porta et al. 1999.)

Firm size proxies for the amount of public information available about a company since much information about larger firms is generated by analysts, competitors, trade groups, and regulatory agencies (Dempsey, 1989; Atiase, 1985). Here, we measure firm size as the $\log$ of the beginning-of-the-period market value of equity (SIZE $\mathrm{E}_{\mathrm{it}}$ ). Prior studies show that the more distant the forecast horizon, the greater will be the error or bias evidenced in the forecast (e.g., Choi and Ziebart, 2000). We measure the forecast horizon, HORIZON $\mathrm{it}$, using the number of months between the initial management earnings forecasts announcement date and the corresponding end of the fiscal year. Poor firm performance in one period is frequently followed by highly optimistic analysts’ earnings forecasts (Matsumoto, 2002; Moses 1990; Klein ,1990; and Choi and Ziebart, 2000). This is consistent with the so-called 'Big Bath' theory of corporate financial

\footnotetext{
${ }^{17}$ We also created a Pyramid variable, to capture the effects of control that is held indirectly, through a nominee corporation. PYRAMID equals one if the controlling shareholder exercises control through at least one publicly traded company, and zero otherwise. It was generally highly correlated to the CV variable. It was not used in the main analysis because of that high correlation $(\mathrm{r}=.63, \mathrm{p}<.0001)$.
} 
reporting. Following these studies, we construct an indicator variable $\mathrm{LOSS}_{\text {it }}$ that we set equal to one if the prior year earnings are negative, and zero otherwise.

Matsumoto (2002) and Richardson et al. (1999) claim that high growth firms have greater incentives to release pessimistic forecasts in order to manage investors' perceptions of the firm. Further, Collins and Kothari (1989) show that a high growth potential is related to a higher earnings response coefficient. This may serve as a reason for corporate managers to engage in an expectations management game. We used the fiscal year's market-to-book ratio to measure the firm's growth potential (Matsumoto (2002), creating $\mathrm{MB}_{\mathrm{it}}$. Firm-years in the electronics industry comprise $53.2 \%$ of our sample. Accordingly, we construct an indicator variable $E_{L E C}$ it set equal to one if firms belong to the electronics industry, and set equal to zero otherwise.

\section{$\underline{\text { Revision in Accuracy, Bias, and Corporate Ownership Structure }}$}

To verify hypotheses 3 and 4, we estimate the following regression:

$$
\begin{aligned}
\operatorname{ABS}\left(\text { REV }_{\mathrm{it}}\right)= & \beta_{0}+\beta_{1} \mathrm{CV}_{\mathrm{it}}+\beta_{2} \text { CROSS }_{\mathrm{it}}+\beta_{3} \text { LSHAR }_{\mathrm{it}}+\beta_{4} \text { SIZE }_{\mathrm{it}}+\beta_{5} \text { HORIZON }_{\mathrm{it}}+ \\
\mathrm{REV}_{\mathrm{it}}= & \beta_{6} \mathrm{LOSS}_{\mathrm{it}}+\beta_{7} \mathrm{MB}_{\mathrm{it}}+\beta_{8} \text { ELEC }_{\mathrm{it}}+\varepsilon_{\mathrm{it}} \\
& \beta_{6} \mathrm{LOSS}_{\mathrm{it}}+\beta_{\mathrm{it}}+\beta_{2} \mathrm{CROSS}_{\mathrm{it}}+\beta_{3} \mathrm{LSHAR}_{\mathrm{it}}+\beta_{8} \mathrm{ELEC}_{\mathrm{it}}+\varepsilon_{\mathrm{it}}
\end{aligned}
$$

The dependent variables $A B S\left(R E V_{i t}\right)$ is defined as the revision in the absolute difference between $\mathrm{FE} 1_{\text {it }}$ and $\mathrm{FE} 2_{\mathrm{it}}$. $\mathrm{REV}$ it is defined as the difference between $\mathrm{FE} 1_{\mathrm{it}}$ and $\mathrm{FE} 2_{\mathrm{it}}$. The control variables are defined in the same way as those of equations (5) and (6). To be consistent with $\mathrm{H} 3$ and $\mathrm{H} 4$, we expect that the coefficients of $\mathrm{CV}_{\text {it }}$ to be negative.

Following the Jaggi et al. (2006), $\mathrm{REV}_{\text {it }}$ can be decomposed into revisions in forecasts, FORREV it, and discretionary accruals TDA $_{i t}$ FORREV it is defined as the difference between initial predictions $\left(\mathrm{PE}_{\mathrm{IN}}\right)$ and the last revision of forecasts $\left(\mathrm{PE}_{\mathrm{LR}}\right)$, 
scaled by total assets. Managers would have two options for reducing the forecast error or bias. They could either revise the forecasts downward, as allowed by the regulation or adjust the reported earnings upward.

\section{Empirical results}

\subsection{Statistical analysis}

Table 3 presents descriptive statistics for selected variables used here. The mean (median) of $\mathrm{FE} 1_{\mathrm{it}}$ is $0.0836(0.0438)$, indicating that the firms tend to release optimistically biased forecasts. The mean of $\mathrm{ABS}\left(\mathrm{FE} 1_{\mathrm{it}}\right)$ indicates that for the average firm, the mean ratio of initial forecast errors to total assets is $18.39 \%$. The mean (median) of $\mathrm{REV}_{\mathrm{it}}, 0.0665$ (0.0336), indicate(s) that the firms tend to reduce the forecast error as the end of the period approaches. Further, the resulting mean (median) of managed forecast error, $\mathrm{FE}_{\mathrm{it}}$, decreases to approximately 0.0170 (0.0074). Similarly, the mean (median) of $\mathrm{ABS}\left(\mathrm{REV}_{\mathrm{it}}\right), 0.1717$ (0.0813), indicates that the firms tend to reduce the absolute forecast error as the end of year approaches. The resulting mean (median) managed forecast error, $\mathrm{ABS}\left(\mathrm{FE} 22_{\mathrm{it}}\right)$, is approximately $0.0283(0.0134)$.

The mean (median) of $\mathrm{CV}_{\text {it }}$ is less than one. This documents the divergence between the ultimate owner's control and his/her equity ownership level. The mean FORREV $_{\text {it }}$ is 0.024, indicating that, on average, firms revise earnings forecasts

downward. The mean TDA is 0.0098 , suggesting that, on average, firms manipulate reported earnings upward. Further, the mean of CROSS $_{i t}$ is 0.0834 , which is significantly positive. Accordingly, this indicates that the ultimate owners use crossshareholdings to leverage their control. Since most variables are significantly skewed to the right we used rank correlations and rank regressions in the sensitivity analyses in 
order to avoid the distorting effects of significant skewness on the calculation of non-rank statistics.

In addition, LSHAR ${ }_{\text {it }}$ 's mean is 0.3958 , indicating that approximately two-fifths of sample firms have at least one shareholder qualified to file suit under Article 214 of Taiwan’s Corporate Law. The median firm size has a log market value of equity of NT\$14.9551, which is equivalent to a market value of NT \$3125.484 million. The mean (median) of HORIZON $\mathrm{H}_{\mathrm{it}}$ is 13.323 (12). This indicates that the typical firm issues its initial forecast during April. The mean of LOSS it is 0.1553 , showing that $15.53 \%$ of sample firms had negative prior year earnings. The mean (median) of $\mathrm{MB}_{\mathrm{it}}$ is 2.0660 (1.5199).

The correlation matrix (not presented) reveals significantly negative Pearson and Spearman correlations between $\mathrm{CV}_{\mathrm{it}}$ and our primary dependent variables in equation (5)(8) ( $p$-value $<0.05$ or 0.01 ), including $F E 1_{i t}, A B S\left(F E 1_{i t}\right), R E V_{i t}$, and $A B S\left(R E V_{i t}\right)$. Thus, the lower the control rights divergence, the greater were the initial levels of forecast error and bias, as predicted. Findings from the regression analyses below provide evidence on the variable associations after controlling for all of the posited effects.

\subsection{Analysis of multiple variables}

\subsubsection{Accuracy of forecast earnings and corporate ownership structure}

Table 4 provides summary statistics from the estimation of equation (5)-(8). Since the regression equations generally suffered from heteroscedasticity problems, we used the White (1980) methodology to adjust the t-statistics to correct this problem. This was done as required, in all regressions. Column (1) of Table 4 shows the regression of $\mathrm{ABS}\left(\mathrm{FE} 1_{\mathrm{it}}\right)$

on the cash-control divergence variable, $\mathrm{CV}_{\mathrm{it}}$. The results showed that the coefficient of $\mathrm{CV}_{\text {it }}$ is negative and statistically significant. This implies that mandatory earnings 
forecast accuracy is negatively associated with the degree of agency problems as captured by cash-control divergence, supporting $\mathrm{H} 1$.

Consistent with our predictions, the coefficient of CROSS $\mathrm{it}_{\text {it }}$ is positively related to the absolute forecast error, as predicted. This relationship, however, is insignificant. As predicted, the coefficient of SIZE $_{\mathrm{it}}$ is negative and significant, indicating that larger firms issue more accurate forecasts. The coefficients of HORIZON ${ }_{i t}$ and LOSS $_{\text {it }}$ are significant and positive, suggesting that forecasts with longer forecast horizons are less accurate and firms with losses tend to announce less accurate forecasts. ${ }^{18}$

Below, we present the results of three further regressions used to test hypotheses 2 through 4. The results for the control variables in those regressions were similar to those reported in our test of hypothesis 1 (see above), derived in estimating equation (5). Therefore, these control variable results are not further described in order to conserve space.

\subsubsection{Bias of forecast earnings and corporate ownership structure}

Column (2) of Table 4 presents summary statistics from estimating equation (6), the regression of $\mathrm{FE} 1_{\mathrm{it}}$, pre-managed mandatory earnings forecast error, on the control divergence variable, $\mathrm{CV}_{\mathrm{it}}$. The results show that the coefficient of $\mathrm{CV}_{\mathrm{it}}$ is negative and statistically significant, as predicted. This supports the alternative of $\mathrm{H} 2$ that the mandatory earnings forecast bias is positively associated with the degree of agency problems as captured by control divergence.

\subsubsection{Revision in forecast accuracy and corporate ownership structure}

\footnotetext{
${ }^{18}$ These results remain quantitatively unchanged when we re-estimate the model using the Belsley, Kuh, and Welsch (1980) influence diagnostics to exclude outliers. These methods were applied to all regressions for forecast errors analyses. The results remained unchanged. Further, in all regressions reported, we conducted multicollinearity diagnostic tests by computing the variance inflation factors (Kennedy, 2000) for all variables used in the regression analyses. None of these factors displayed a value greater than 2.0, thus indicating a lack of multicollinearity. This held true in all regressions.
} 
Column (3) of Table 4 reports summary statistics from estimating equation (7), the regression of $\mathrm{ABS}\left(\mathrm{REV}_{\mathrm{it}}\right)$, absolute revision in earnings forecast, on proxies for the ultimate owners' cash-control divergence. Consistent with our prediction, $\mathrm{CV}_{\mathrm{it}}$ is negative and statistically significant. This suggests that the revision in the mandatory earnings forecast is positively associated with the degree of agency problems as captured by the cash-control divergence variable. This result lends support to H3 that firms with more serious agency problems tend to revise their forecasts more, thereby reducing the amount of forecast error in the ultimate forecast.

\subsubsection{Revision in forecast optimism and corporate ownership structure}

Column (4) of Table 4 presents summary statistics from estimating equation (8), the regression of $\mathrm{REV}_{\mathrm{it}}$, revision in mandatory earnings forecast error, on proxies for the ultimate owners' cash-control rights divergence. As predicted, the coefficient of $\mathrm{CV}_{\mathrm{it}}$ is negative and statistically significant, indicating that the revisions in mandatory earnings forecast bias are positively associated with the degree of agency problems as these are captured by the control divergence variable. This lends support for $\mathrm{H} 4$.

[Insert Table 4 here]

\subsection{Additional analyses}

As described above, firms with serious agency problems are more likely to issue inaccurate or optimistic forecasts, and then act to not exceed the forecast errors threshold. The results are consistent with prior findings by Jaggi et al (2006). To provide further insights into forecasting behaviors, we present three additional analyses here.

As our first diagnostic checks, we run the regressions illustrated in equations (5) and (6) by replacing the absolute value of initial forecast error, ABS (FE1), and initial forecast error, FE1, by their respective absolute values of post-managed forecast errors, 
ABS(FE2), and post-managed forecast errors, FE2. ABS(FE2) is defined as the absolute value of differences between the last revision of forecasts and reported earnings. FE2 is defined as the post-managed forecast errors. The results of these tests, not shown here, illustrate that all proxies for corporate ownership structure are positively, but not significantly, related to the absolute value of post-managed forecast errors ABS (FE2) and post-managed forecast errors (FE2). The results suggest that firms with greater agency problems tended to have greater initial deviations from the forecast threshold, and later tended to either revise their forecasts downward or/and manipulate reported earnings, thereby reducing forecast error. This led to no significant difference in managed forecast errors across issuers.

We further investigate the effect of earnings forecast revisions and discretionary accruals adjustments on shrinking earnings forecast errors. Jaggi et al (2006) document that the firms issued more optimistic forecasts than conservative forecasts, while firms disclosing optimistic mandatory forecasts adjusted their reported earnings upward or revised their forecasts downward. To follow up on Jaggi’s findings, we re-ran equation (8) by using revisions in forecast, FORREV $\mathrm{i}_{\mathrm{it}}$, and total discretionary accruals TDA as dependent variables, respectively, rather than forecast errors. FORRE $V_{i t}$ is defined as the difference between initial predictions $\left(\mathrm{PE}_{\mathrm{IN}}\right)$ and the last revision of forecasts $\left(\mathrm{PE}_{\mathrm{LR}}\right)$, scaled by total assets. The results of these tests are shown in columns (5) and (6) of Table 4, respectively. The results show that FORREV $V_{\text {it }}$ and TDA are significantly and negatively related to the proxies for agency problems. This indicates that firms with agency problems reduce forecast errors in order to stay within the forecast threshold. Reducing forecast error is done by either revising forecasts downward and/or 
manipulating discretionary accruals upward. The result is no significant difference in managed forecast errors across issuers.

Third, the TSFEC's regulation on mandatory forecasts requires issuers to reveal forecasts for the IPO year and the next two years subsequent to the issuance of the IPO. We used a random effects model to test for the presence of serial correlation and found that this was not a problem. Given the unbalanced panel in our sample, we repeated the tests using a random effects model. We found results similar to the prior analysis.

\subsection{Sensitivity analyses}

Choice of earnings management proxies may have an effect on measures of the primary variables, including pre-managed forecast error (FE1), absolute pre-managed forecast error (ABS(FE1)), revision in pre-managed forecast error (REV), and absolute revision in pre-managed forecast error (ABS(REV)). This, in turn, would affect the validity of our inferences.

We use three different types of discretionary accruals to overcome the weaknesses in measuring the discretionary accruals, thus helping establish the validity of our findings. First, based on work by Kasznik (1999), Bartov et al. (2000), and Kothari et al. (2005), we controlled for reversals of prior years' accruals or growth patterns in earnings in order to avoid erroneous inferences. Second, based on the work of Dechow (1994), Dechow et al. (1995); Klein (2002), DuCharme et al. (2001), and Jaggi and Lee (2002), who argued that total accruals are negatively related to operating cash flows even in the absence of any systematic earnings management, we examined the pattern of operating cash flows. Finally, current discretionary accruals are also used to test our hypotheses (e.g. Ashbaugh

et al., 2003; Becker, et al., 1998; Frankel, et al., 2002). Untabulated results show that the 
primary conclusions remained unchanged using the different kinds of discretionary accruals to calculate the forecast error or bias.

As shown in Table 3, most variables in our analyses are skewed to the right. To reduce the potential effects of outliers, and to ensure a normal distribution of the error terms for our sample, we transformed the dependent and independent variables using Rank Regression, and then re-ran the regression analyses. The results of the alternate analyses were consistent with the analyses reported above.

\section{Discussion and Concluding Remarks}

Weak corporate governance in East Asian countries leads to low levels of transparency and low disclosure quality, and may have led to the late 1990's Asian financial crisis. Hence, improving corporate governance has been a critical task for Asian governments. The agency problem arises from the divergence between ultimate controlling owners' cash flow rights and voting rights. To improve transparency and disclosure quality of listed firms, new accounting and disclosure standards, including the regulation of mandatory earnings forecasts, were imposed by the TSFEC. This study investigates the association between the mandatory earnings forecast quality, as measured by forecast accuracy and bias, and the ownership structure of Taiwanese firms as measured by control divergence.

Our results document that concentrated ownership, and its associated crossholding structures, created agency conflicts between controlling owners and outside investors. Listed firms tended to issue less accurate and more optimistically biased forecasts in the presence of greater control divergence. These findings suggest that the ultimate controlling owners have incentives to benefit themselves by issuing 
uninformative or optimistically biased forecasts. We further found that listed firms tended to revise their forecasts or manage earnings (e.g. through discretionary accruals). Firms with relatively more serious agency problems tended to engage in greater revisions as the end of the period approached. Accordingly, the resulting post-managed forecast error or bias did not significantly vary with the level of concentrated voting rights control by the end of the year.

This paper contributes to several streams of literature. First, this is the first attempt to examine how agency conflicts between controlling and other shareholders affect earnings forecasts in a very different ownership context from that seen in research on UK and US corporations. The latter two contexts have widely diffuse ownership structures and less divergence between voting and cash flow rights. Secondly, we also contribute to the literature on earnings forecasts by examining the impact of governance mechanisms on mandatory earnings forecasts. The empirical evidence about the impact of ownership structure on mandatory management earnings forecasts has not been addressed although there have been previous studies regarding voluntary disclosure practices. Our findings indicate that firms with serious agency problems initially make less accurate and more optimistically biased earnings forecasts. These firms then tend to revise forecast errors or biases more to avoid violating the threshold requirements.

Finally, the findings of our study have policy implications for Taiwan as well as other countries in the Asian Pacific Basin region. There is growing discussion about the importance of achieving substantial corporate governance reforms in the Asian Pacific Basin countries. This discussion is apiece with that currently taking place in the United States after the imperfections of the US market were made plain by recent corporate scandals. 
Some developing countries currently require compulsory disclosure of earnings forecasts. For example, firms making initial public offerings in Malaysia, New Zealand, Singapore, and Taiwan are required to provide earnings forecasts. There, the market is assumed to be imperfect. Thus, regulation is needed to level the playing field. Our findings can provide some further insights to East Asian policy makers and regulators about the effects of concentrated ownership in the East Asian region on management earnings forecasts. The regulators can then amend board governance and earnings forecasts requirements to increase the transparency of board activities and to provide a richer information environment. Speaking broadly, our findings suggest that policy makers should take into consideration a country's institutional environment before prescribing a comprehensive set of rules and regulations for financial reporting (Ball et al., 2000, and Leuz et al., 2003).

One potential limitation is, as Haw et al. (2004, p. 437; Claessens et al., 2000) noted with respect to their own control divergence study, "diverge" (our CV) "is likely to measure the control divergence with error because the data on the ultimate owners' control and cash flow rights are constructed using only listed corporations. If unlisted corporations have ownership links with listed firms, the estimates for control and ownership may be underestimated (Claessens, Djankov, and Lang, 2000), and this measurement error is potentially increased for firms in countries where stock markets and legal and extra-legal infrastructures are not well developed.” This is true here, as well. We believe, however, that variance caused by the existence of any such error is most likely to work against supporting our hypotheses, not for it. While the effect of unmeasured variables must always be uncertain, it seems logical that only systematic variance is likely to generate support for a hypothesized statistical relationship. 


\section{Reference}

Ajinkya, B B., and M. J. Gift. 1984, “Corporate managers' earnings forecasts and symmetrical adjustments of market expectations," Journal of Accounting Research :425-444.

Ajinkya B., S. Bhojraj, and P. Sengupta, 2005, "The association between outside directors, institutional investors and the properties of management earnings forecasts," Journal of Accounting Research 43 (3): 343-376.

Ashbaugh, H., R. Lafond, and B. W. Mayhew, 2003, “Do nonaudit services compromise auditor independence? Further evidence,” The Accounting Review 78 (3): 611-639.

Atiase, R., 1985, "Predisclosure information, firm capitalization, and security price behavior around earnings announcements," Journal of Accounting Research 23 (Spring): 21-36.

Ball, R., S. Kothari, and A. Robin. 2000, "The effect of international institutional factors on properties of accounting earnings,” Journal of Accounting and Economics 29: 152.

Bartov, E., F. A. Gul, and J. S. L. Tsui, 2000, "Discretionary accruals models and audit qualification,” Journal of Accounting and Economics 30: 421-452.

Becker, C. L., M. L. Defond, K. Jiambalvo, and R. Subramanyam, 1998, “The effect of audit quality on earning management," Contemporary Accounting Research 15 (Spring): 1-24.

Belsley, D., E. Kuh, and R. Welsch, 1980, Regression diagnostics (Wiley, New York, NY).

Chin, C. C., H. W. Lin, and M. F. Lin, 2002, "On the association between IPO anomalies and management forecasts,” International Journal of Accounting Studies 34: 31-56.

Choi, J. H. and D. A. Ziebart, 2000, “A reexamination of bias in management earnings forecasts,” Working paper, Hong Kong University of Science and Technology.

Claessens, S., S. Djankov, J. Fan, and H. P. Lang, 1999, "Expropriation on minority shareholders: Evidence form East Asia,” Policy research working paper 2088, The World Bank.

Claessens, S., S. Djankov, and L. H. P. Lang, 2000, "The separation of ownership and control in East Asian corporation,” Journal of Financial Economics 58: 81-112.

Claessens, S., S. Dajankov, and L. H. P. Lang, 2002, “ Disentangling the incentive and entrenchment effects of large shareholding,” Journal of Finance 56 (6): 2741-2771.

Clarkson, P.M., A. Dontoh, G. Richardson, and S.E. Sefcik, 1992, “The voluntary inclusion of earnings forecasts in IPO prospectuses," Contemporary Accounting Research 8 (2): 601-626.

Collins, D. W. and S. P. Kothari, 1989, “An analysis of intertemporal and cross-sectional determinants of earnings response coefficients," Journal of Accounting and Economics (2): 143-181. 
Dech ow, P. M., 1994, "Accounting earnings and cash flows as measures of firm performance: The role of accounting accruals," Journal of Accounting and Economics 17: 3-42.

Dechow, P. M., R. G. Sloan, and A. P. Sweeney, 1995, "Detecting earnings management,” The Accounting Review, 70 (April): 193-225.

Dechow, P. M., R. G. Sloan, and A. P. Sweeney, 1996, "Causes and consequences of earnings manipulations: An analysis of firms subject to enforcement actions by the SEC," Contemporary Accounting Research 13: 1-36.

Dempsy, S., 1989, " Predisclosure information search incentive, analyst following, and earnings announcement price response,” The Accounting Review 64 (October): 748757.

DuCharme, L. L., P. H. Malatesta, and S. E. Sefcia, 2001, "Earnings management: IPO valuation and subsequent performance," Journal of Accounting, Auditing, and Finance 16 (4): 369-396.

Fan, P. H., and T. J. Wong, 2002, "Corporate ownership structure and the informativeness of Accounting Earnings in East Asia," Journal of Accounting and Economics,33 (August): 401-425.

Fan, P. H., and T. J. Wong, 2005, "Do external auditors perform a corporate governance role in emerging markets? Evidence form East Asia," Journal of Accounting Research 43:35-38.

Frank, R. and E. Cherney, 2004, "Paper Tigers: Lord Black's Board: A-List Cast Played Acquiescent Role. Wall Street Journal, p. A1, visited at www.wsj.com on September 27, 2004.

Frankel, R. M.. M. McNichols, and G. Wilson, 1995, "Discretionary disclosure and external financing," The Accounting Review 70: 135-150.

Frankel, R. M., M. F. Johnson, and K. K. Nelson, 2002, “The relation between auditor's fees for nonaudit services and earnings management,” The Accounting Review 77 (Supplement), 71-115.

Haw, I. M., B. B. Hu, L. S. Hwang, and W. Wu, 2004, "Ultimate ownership, income management, and legal and extra-legal institutions," Journal of Accounting Research 42: 423-426.

Jaggi, B. and P. Lee, 2002, "Earnings management response to debt covenant violations and debt restructuring," Journal of Accounting, Auditing, and Finance 17 (4): 295-324.

Jaggi, B., C. Chin, H-W Lin, and P. Lee, 2006, "Earnings forecast disclosure regulation and earnings management: Evidence from Taiwan IPO firms," Review of Quantitative Finance \& Accounting 26 (3), Forthcoming.

Jensen, M. C. and W. H. Meckling, 1976, "Theory of the firm: managerial behavior, agency costs and ownership structure”, Journal of Financial Economics 3: 305-336.

Karamanou, I., and N. Vafeas, 2005, "The association between corporate boards, audit committees, and management earnings forecasts: An empirical analysis," Journal of Accounting Research 43 (3): 453-486. 
Kasznik, R., 1999, "On the association between voluntary disclosure and earnings management," Journal of Accounting Research 37 (Spring): 57-81.

Kennedy, P., 2000, A Guide to Econometrics, Blackwell publisher, $4^{\text {th }}$ edition.

Klein, A., 1990, "A direct test of the cognitive bias theory of share price reversals," Journal of Accounting and Economics 13(2): 155-166.

Klein, A., 2002, "Audit committee, board of director characteristics, and earnings management," Journal of Accounting and Economics 33 (August): 375-400.

Ko, Chen-en, K. Ding, C. Liu and Y. Yeh, 1999, "Corporate governance in Chinese Taipei," Proceeding paper in the conference on "Corporate Governance in Asia: A Comparative Perspective," held in Seoul, South Korea.

Kothari, S. P., A. Leone, and C. Wasley, 2005, "Performance matched discretionary accrual measures," Journal of Accounting \& Economics 39 (1): 163-197.

La Porta, R., F. Lopez-de-Silanes, A. Shleifer, and R. W. Vishny, 1998, "Law and finance,” Journal of Political Economy 106: 1113-1155.

La Porta, R., F. Lopez-de-Silanes, and A. Shleifer, 1999, "Corporate ownership around the world," Journal of Finance 54: 471-517.

La Porta, R., F. Lopez-de-Silanes, A. Shleifer, and R. W. Vishny, 2002, "Investor protection and corporate valuation," Journal of Finance 57: 1147-1170.

Lavelle, L., August 25, 2004, "Google's governance falls way short," Business Week Online, visited on August 27, 2004.

Leuz, C., D. Nanda, and P. Wysocki, 2003, "Earnings management and institutional factors: An international comparison,” Journal of Financial Economics: 505-527.

Matsumoto, E., 2002, "Management's incentives to avoid negative earnings surprises," The Accounting Review 77 (3): 483-514.

McKinnon, J. D. and J. R. Hagerty, 2004, Fannie Mae overseer to present report criticizing accounting, The Wall Street Journal, September 20, 2004, Page A2. Visited on September 20, 2004, at http: // online. wsj.com /article/ 0, SB109563119263921750,00.html?mod=home_whats_news_us

Morgenson, G., 2004, “A door opens: The view is ugly—Mutual fund board voting,” The New York Times, September 12, 2004. Viewed at www.nytimes.com on September 13, 2004.

Moses, O. D., 1990, "On analysts' earnings forecasts for failing firms." Journal of Business, Finance \& Accounting 17(1): 1101-1118.

Patell, J., 1976, "Corporate forecasts of earnings per share and stock price behavior: Empricial tests,” Journal of Accounting Research: 246-276.

Richardson, S., S. H. Teoh, and P. Wysocki, 1999, “Tracking analysts' forecasts over the annual earnings horizon: Are analysts' forecasts optimistic or pessimistic?” Working Paper, University of Michigan at Ann Arbor.

Rajgopal, S., M. Venkatachalam, and J. Jiambalvo, 2002, "Is Institutional Ownership Associated with Earnings Management and the Extent to which Stock Prices Reflect Future Earnings?” Contemporary Accounting Research 19 (1): 117-136. 
Shleifer, A., and R. Vishny, 1997, "A survey of corporate governance," Journal of Financial Economics 53: 737-783.

Taipei Times, July 18, 2002, "Corporate scandal old hat in Asia."

Teoh, S., I. Welch, and T. Wong, 1998, "Earnings management and the underperformance of seasoned equity offerings," Journal of Financial Economics 50: 6399.

Wang, Y-F, P Lee, C. L. Chin and G. Kleinman, 2005, "The impact of Taiwan financial forecasts regulation on IPO anomalies: Long term performance.," Journal of Financial Regulation and Compliance 3 (2) :146-166.

Waymire, G., 1984, "Additional evidence on the information content of management earnings forecasts," Journal of Accounting Research: 703-718.

White, H., 1980, "A heteroscedasticity-consistent covariance matrix estimator and direct test for heteroscedasticity," Econometrica, 48: 817-838.

Williams, P., 1996, "The relation between a prior earnings forecast by management and analyst response to a current management forecast," The Accounting Review 71: 103-13.

Yeh, Y. H., P. G. Shu, and W. Y. Huang, 2001, "The year-end anomaly of Taiwan family control groupings,” Review of Pacific Basin Financial Markets and Policies 4 (2): 127-163.

Yeh, Y. H., and T. S. Lee, 2002, "Corporate governance and corporate equity investments: evidence from Taiwan," The $9^{\text {th }}$ Global Finance conference, Beijing, China.

Yeh, Y. H., T. S. Lee, and C. E. Ko, 2002, Corporate Governance and Rating System, (Sunbright Publishing Co., Taipei)

Zun, W. M., September 2, 2002, "The difficulties of improving Taiwanese corporate governance,” Economy Daily, Taipei, Taiwan. 
TABLE 1

Firm-year and Firm-industry Distribution

\begin{tabular}{|c|c|c|c|c|}
\hline \multicolumn{5}{|c|}{ Panel A: Firm-year distribution from 1999 to 2001} \\
\hline Year & 1999 & 2000 & 2001 & Total \\
\hline Firm & 164 & 193 & 171 & 528 \\
\hline$\%$ & 31.06 & 36.55 & 32.39 & 100 \\
\hline \multicolumn{5}{|c|}{ Panel B: Sample firm industry distribution } \\
\hline TSE Industry Code & \multirow{2}{*}{\multicolumn{2}{|c|}{$\begin{array}{c}\text { Industries } \\
\text { Cement }\end{array}$}} & Number of firms & Sample percentage \\
\hline 01 & & & 1 & 0.19 \\
\hline 02 & \multicolumn{2}{|c|}{ Foods } & 14 & s2.65 \\
\hline 03 & \multicolumn{2}{|c|}{ Plastics } & 17 & 3.22 \\
\hline 04 & \multicolumn{2}{|c|}{ Textiles } & 31 & 5.87 \\
\hline 05 & \multicolumn{2}{|c|}{ Electric \& machinery } & 29 & 5.49 \\
\hline 06 & \multicolumn{2}{|c|}{ Electric Appliance \& Cable } & 10 & 1.89 \\
\hline 07 & \multicolumn{2}{|c|}{ Chemicals } & 20 & 3.79 \\
\hline 08 & \multicolumn{2}{|c|}{ Glass \& Ceramics } & 10 & 1.89 \\
\hline 09 & \multicolumn{2}{|c|}{ Papermaking } & 3 & 0.57 \\
\hline 10 & \multicolumn{2}{|c|}{ Steel \& Iron } & 29 & 5.49 \\
\hline 11 & \multicolumn{2}{|c|}{ Rubber } & 5 & 0.95 \\
\hline 13 & \multicolumn{2}{|c|}{ Electronics } & 281 & 53.22 \\
\hline 14 & \multicolumn{2}{|c|}{ Construction } & 25 & 4.73 \\
\hline 15 & \multicolumn{2}{|c|}{ Transportation } & 10 & 1.89 \\
\hline 16 & \multicolumn{2}{|c|}{ Tourism } & 3 & 0.57 \\
\hline 18 & \multicolumn{2}{|c|}{ Wholesale \& Retail } & 7 & 1.33 \\
\hline 20 & \multicolumn{2}{|c|}{ Others } & 23 & 4.36 \\
\hline 21 & \multicolumn{2}{|c|}{ Biotechnology } & 3 & 0.57 \\
\hline 22 & \multicolumn{2}{|c|}{ Communication } & 1 & 0.19 \\
\hline 23 & \multicolumn{2}{|c|}{ Software } & 6 & 1.14 \\
\hline & \multicolumn{2}{|c|}{ Total } & $\underline{528}$ & $\underline{100}$ \\
\hline
\end{tabular}


TABLE 2

\section{Variable definition}

\begin{tabular}{|c|c|}
\hline Variable & Definition \\
\hline$F E 1_{\text {it }}$ & 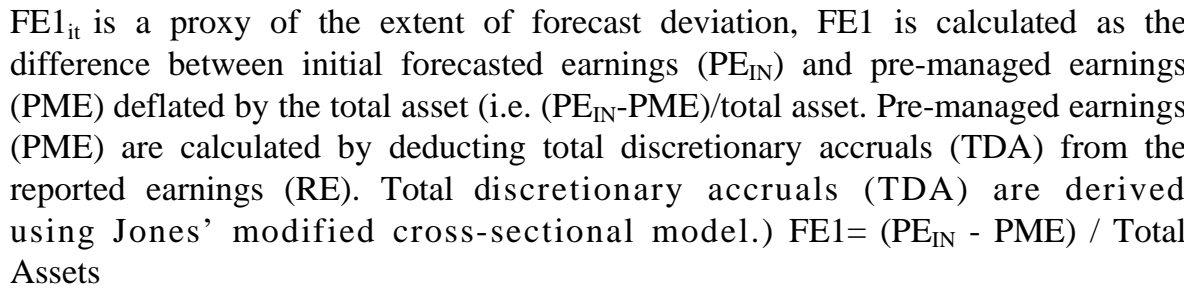 \\
\hline $\operatorname{ABS}\left(F E 1_{i t}\right)$ & $\mathrm{ABS}\left(\mathrm{FE} 1_{\mathrm{it}}\right)$ is used to measure forecast accuracy \\
\hline $\mathrm{FE} 2_{\mathrm{it}}$ & $\begin{array}{l}\text { Forecast error FE2 is calculated as the difference between last revision of } \\
\text { forecasts }\left(\mathrm{PE}_{\mathrm{LR}}\right) \text { and reported earnings }(\mathrm{RE}) \text {. } \mathrm{FE} 2=\left(\mathrm{PE}_{\mathrm{LR}}-\mathrm{RE}\right) / \text { Total Assets }\end{array}$ \\
\hline $\operatorname{ABS}\left(F E 2_{i t}\right)$ & Absolute FE2 \\
\hline $\mathrm{REV}_{\text {it }}$ & $\mathrm{REV}=\mathrm{FE} 1-\mathrm{FE} 2$ \\
\hline $\mathrm{ABS}\left(\mathrm{REV}_{\mathrm{it}}\right)$ & Absolute REV \\
\hline $\mathrm{CV}_{\text {it }}$ & $\mathrm{CV}$ is the cash flow rights over voting rights \\
\hline $\mathrm{CROSS}_{\mathrm{it}}$ & $\begin{array}{l}\text { CROSS equals one if the firm both has a controlling shareholder and owns shares in } \\
\text { its controlling shareholder or in a firm that belongs to her chain of control, and zero } \\
\text { otherwise. }\end{array}$ \\
\hline FORREV $_{\text {it }}$ & $\begin{array}{l}\text { Revision in forecast. It is defined as the difference between the initial predictions } \\
\left(\mathrm{PE}_{\mathrm{IN}}\right) \text { and the last forecast, as revised by the issuing firm }\left(\mathrm{PE}_{\mathrm{LR}}\right) \text {, scaled by total } \\
\text { assets. }\end{array}$ \\
\hline $\mathrm{TDA}_{\mathrm{it}}$ & Total discretionary accruals. \\
\hline LSHAR $_{\mathrm{it}}$ & $\begin{array}{l}\text { LSHAR equals one if the firm have 3\% shareholder other than ultimate owner, and } \\
\text { zero otherwise. }\end{array}$ \\
\hline $\mathrm{SIZE}_{\mathrm{it}}$ & SIZE measure by the log of the beginning-of-the-period market value of equity \\
\hline HORI & $\begin{array}{l}\text { HORIZON is number of months between initial management earnings forecasts } \\
\text { announcement date and corresponding the end of April in the next year. }\end{array}$ \\
\hline LOSS $_{\text {it }}$ & LOSS equals one if the prior year earnings are negative, and zero otherwise \\
\hline $\mathrm{MB}_{\mathrm{it}}$ & MB is fiscal year's beginning market-to-book ratio. \\
\hline ELEC $_{\text {it }}$ & ELEC $_{\text {it }}$ set equal to one if firms belong to electronics industry, and zero otherwise. \\
\hline
\end{tabular}


TABLE 3

Descriptive Statistics on Variables for Sample Firms (1999-2001)

\begin{tabular}{|c|c|c|c|c|c|}
\hline Variable & Mean & Std. Dev. & $\begin{array}{l}25 \% \\
\text { Quartile }\end{array}$ & $\begin{array}{l}50 \% \\
\text { Median }\end{array}$ & $\begin{array}{l}75 \% \\
\text { Quartile }\end{array}$ \\
\hline$\overline{\mathrm{FE} 1_{\text {it }}}$ & 0.0836 & 0.3198 & -0.0338 & 0.0438 & 0.1497 \\
\hline $\mathrm{ABS}\left(\mathrm{FE} 1_{\mathrm{it}}\right)$ & 0.1839 & 0.2745 & 0.0386 & 0.0890 & 0.2112 \\
\hline $\mathrm{FE} 2_{\text {it }}$ & 0.0170 & 0.0608 & -0.0024 & 0.0074 & 0.0226 \\
\hline $\mathrm{ABS}\left(\mathrm{FE} 2_{\mathrm{it}}\right)$ & 0.0283 & 0.0564 & 0.005 & 0.0134 & 0.0283 \\
\hline $\mathrm{REV}_{\text {it }}$ & 0.0665 & 0.3013 & -0.0453 & 0.0336 & 0.1358 \\
\hline $\mathrm{ABS}\left(\mathrm{REV}_{\mathrm{it}}\right)$ & 0.1717 & 0.2562 & 0.0373 & 0.0813 & 0.2008 \\
\hline FORREV $_{\text {it }}$ & 0.0240 & 0.0687 & 0 & 0 & 0.0557 \\
\hline $\mathrm{TDA}_{\mathrm{it}}$ & 0.0098 & 0.1245 & -0.0529 & 0.0013 & 0.0680 \\
\hline $\mathrm{CV}_{\mathrm{it}}$ & 0.7863 & 0.3385 & 0.6310 & 1 & 1 \\
\hline CROSS $_{\text {it }}$ & 0.0834 & 0.2768 & 0 & 0 & 0 \\
\hline $\mathrm{LSHAR}_{\mathrm{it}}$ & 0.3958 & 0.4894 & 0 & 0 & 1 \\
\hline SIZE $_{\mathrm{it}}$ & 15.1405 & 1.2881 & 14.1930 & 14.9551 & 15.8260 \\
\hline HORIZON $_{\mathrm{it}}$ & 13.3238 & 2.7999 & 12 & 12 & 15 \\
\hline LOSS $_{\text {it }}$ & 0.1553 & 0.3625 & 0 & 0 & 0 \\
\hline $\mathrm{MB}_{\text {it }}$ & 2.0660 & 1.8216 & 0.91068 & 1.5199 & 2.4704 \\
\hline
\end{tabular}


TABLE 4

Regression Analysis of Cross-Sectional Relationship Between Corporate Ownership Structure and Forecast Error

\begin{tabular}{|c|c|c|c|c|c|c|c|}
\hline "Column \# & & $(1)$ & $(2)$ & (3) & $(4)$ & $(5)$ & (6) \\
\hline "Variables & Predicted Sign & ABS(FE1 $\left.{ }_{\text {it }}\right)$ & $\overline{F E 1_{\text {it }}}$ & ABS(REV $\left.{ }_{\mathrm{it}}\right)$ & $\overline{\mathrm{REV}_{\text {it }}}$ & 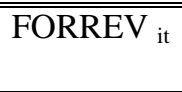 & $\overline{\text { TDA }_{\text {it }}}$ \\
\hline Constant & & $\begin{array}{c}-0.6423 \\
\left(-3.68^{* * *}\right)\end{array}$ & $\begin{array}{l}-0.3383 \\
\left(-1.40^{*}\right)\end{array}$ & $\begin{array}{c}-0.4893 \\
\left(-2.88^{* * *}\right)\end{array}$ & $\begin{array}{l}-0.3696 \\
\left(-1.63^{*}\right)\end{array}$ & $\begin{array}{l}0.0406 \\
(0.99)\end{array}$ & $\begin{array}{c}-0.1635 \\
\left(-1.93^{* *}\right)\end{array}$ \\
\hline $\mathrm{CV}_{\text {it }}$ & - & $\begin{array}{c}-0.0765 \\
(-2.02 * *)\end{array}$ & $\begin{array}{l}-0.1416 \\
\left(-1.43^{*}\right)\end{array}$ & $\begin{array}{c}-0.1834 \\
(-2.18 * *)\end{array}$ & $\begin{array}{c}-0.1607 \\
\left(-1.95^{* *}\right)\end{array}$ & $\begin{array}{c}-0.0381 \\
\left(-1.88^{* *}\right)\end{array}$ & $\begin{array}{l}-0.0516 \\
\left(-1.49^{*}\right)\end{array}$ \\
\hline CROSS $_{\text {it }}$ & + & $\begin{array}{l}0.0531 \\
(1.13)\end{array}$ & $\begin{array}{l}0.0364 \\
(0.62)\end{array}$ & $\begin{array}{l}0.0688 \\
(1.48 *)\end{array}$ & $\begin{array}{c}0.0316 \\
(0.57)\end{array}$ & $\begin{array}{l}-0.0061 \\
(-0.54)\end{array}$ & $\begin{array}{l}0.0140 \\
(0.68)\end{array}$ \\
\hline LSHAR $_{\text {it }}$ & - & $\begin{array}{l}0.0085 \\
(0.34)\end{array}$ & $\begin{array}{l}-0.0010 \\
(-0.03)\end{array}$ & $\begin{array}{l}0.0209 \\
(0.82)\end{array}$ & $\begin{array}{l}0.0152 \\
(0.52)\end{array}$ & $\begin{array}{l}-0.0076 \\
(-1.24)\end{array}$ & $\begin{array}{l}-0.0164 \\
\left(-1.48^{*}\right)\end{array}$ \\
\hline ELEC $_{\text {it }}$ & $?$ & $\begin{array}{l}0.0196 \\
(0.76)\end{array}$ & $\begin{array}{l}0.0198 \\
(0.62)\end{array}$ & $\begin{array}{l}0.0077 \\
(0.29)\end{array}$ & $\begin{array}{l}0.0131 \\
(0.44)\end{array}$ & $\begin{array}{l}0.0100 \\
\left(1.57^{*}\right)\end{array}$ & $\begin{array}{l}0.0056 \\
(0.50)\end{array}$ \\
\hline SIZE $_{i t}$ & - & $\begin{array}{c}-0.0428 \\
\left(-4.20^{* * *}\right)\end{array}$ & $\begin{array}{c}-0.0253 \\
\left(-2.00^{* *}\right)\end{array}$ & $\begin{array}{c}-0.0379 \\
\left(-3.75^{* * *}\right)\end{array}$ & $\begin{array}{c}-0.0272 \\
\left(-2.30^{* * *}\right)\end{array}$ & $\begin{array}{l}-0.0024 \\
(-1.00)\end{array}$ & $\begin{array}{c}-0.0096 \\
\left(-2.17^{* *}\right)\end{array}$ \\
\hline HORIZON $_{\text {it }}$ & + & $\begin{array}{l}0.0066 \\
(1.52 *)\end{array}$ & $\begin{array}{c}0.0117 \\
\left(2.15^{* *}\right)\end{array}$ & $\begin{array}{c}0.0082 \\
\left(1.90^{* *}\right)\end{array}$ & $\begin{array}{c}0.0118 \\
(2.32 * *)\end{array}$ & $\begin{array}{c}0.0023 \\
\left(2.26^{* *}\right)\end{array}$ & $\begin{array}{l}0.0031 \\
\left(1.64^{*}\right)\end{array}$ \\
\hline LOSS $_{\text {it }}$ & + & $\begin{array}{c}0.1556 \\
\left(4.56^{* * *}\right)\end{array}$ & $\begin{array}{c}0.1991 \\
\left(4.67^{* * *}\right)\end{array}$ & $\begin{array}{c}0.1483 \\
\left(4.28^{* * *}\right)\end{array}$ & $\begin{array}{c}0.1811 \\
\left(4.55^{* * *}\right)\end{array}$ & $\begin{array}{c}0.0331 \\
\left(3.95^{* * *}\right)\end{array}$ & $\begin{array}{l}0.0101 \\
(0.68)\end{array}$ \\
\hline $\mathrm{MB}_{\text {it }}$ & - & $\begin{array}{l}0.0021 \\
(0.30)\end{array}$ & $\begin{array}{l}-0.0011 \\
(-0.13)\end{array}$ & $\begin{array}{l}-0.0006 \\
(-0.09)\end{array}$ & $\begin{array}{l}-0.0007 \\
(-0.09)\end{array}$ & $\begin{array}{c}-0.0047 \\
\left(-2.78^{* * *}\right)\end{array}$ & $\begin{array}{c}-0.0136 \\
\left(-4.39^{* * *}\right)\end{array}$ \\
\hline F-value & & $5.75^{* * *}$ & $4.27 * * *$ & $6.07 * * *$ & $4.43^{* * *}$ & $5.30 * * *$ & $5.44 * * *$ \\
\hline Adj. $\mathrm{R}^{2}$ & & 0.0674 & 0.0474 & 0.0715 & 0.0563 & 0.0614 & 0.0632 \\
\hline
\end{tabular}

Asterisks denote significance levels at the one-tailed test: *** $1 \%, * * 5 \%, * 10 \%$. 